\title{
Municipal Solid Waste Management Practices for Achieving Green Architecture Concepts in Addis Ababa, Ethiopia
}

\author{
Eshetu Gelan
}

Citation: Gelan, E. Municipal Solid Waste Management Practices for Achieving Green Architecture Concepts in Addis Ababa, Ethiopia. Technologies 2021, 9, 48. https:// doi.org/10.3390/technologies 9030048

Academic Editor: Manoj Gupta

Received: 26 May 2021

Accepted: 6 July 2021

Published: 11 July 2021

Publisher's Note: MDPI stays neutral with regard to jurisdictional claims in published maps and institutional affiliations.

Copyright: (c) 2021 by the author Licensee MDPI, Basel, Switzerland. This article is an open access article distributed under the terms and conditions of the Creative Commons Attribution (CC BY) license (https:// creativecommons.org/licenses/by/ $4.0 /)$.
Department of Architecture, School of Civil Engineering and Architecture, Adama Science and Technology University (ASTU), Adama P.O. Box 1888, Ethiopia; eshetu.tgelan@gmail.com

\begin{abstract}
Solid waste is one of the social and environmental challenges that urban areas are facing. The study assesses the state of solid waste in Addis Ababa during 2016-2020 to provide implications for achieving green architecture concepts through better management of solid waste and its economic contribution. The study uses secondary and primary data. Quantitative and qualitative data are analyzed through descriptive statistics and context analysis, respectively. The result reveals that most solid waste is generated from households, followed by commercial centers, street sweeping, industries/factories, hotels, and hospitals, respectively. From 2016 to 2020, an average of $80.28 \%$ of solid waste is collected, whereas $19.72 \%$ of the waste is not collected. There are little or no efforts made to segregate solid waste at the source. The generated waste is disposed of in the Reppi open landfill. Together with Ethiopian electric power (EEP) and the City Government of Addis Ababa, waste has been converted to energy since 2019. The study suggests minimizing waste from its source by reducing generation, composting, reusing, recycling, waste-to-energy strategy, and welldesigned buildings to achieve the concept of green architecture in Addis Ababa through better solid waste management.
\end{abstract}

Keywords: energy; environmental impact; households; landfill; municipal solid waste

\section{Introduction}

Increasing populations, urbanization, industrialization, and changing consumption patterns results in the generation of increasing amounts of solid waste and its diversification [1-5]. Solid waste comprises all the wastes arising from human activities that are normally solid, discarded as useless or unwanted by-products of process lines or materials that may be required by law to be disposed of [6-8]. It has become a recurring feature in the urban environment [1,4-9], and it is the most visible environmental problem among many in urban areas [5-10].

Solid waste collection services are challenging in most areas of developing cities [11]; an estimated $30-50 \%$ of solid waste generation within urban centers is left uncollected [12]. It accumulates on streets and open spaces between houses, causing or contributing to serious health problems. The poorer households suffer most, since it is overwhelmingly in the poorer areas of cities that there are no services to collect garbage or the services are very inadequate [13]. Solid Waste Management (SWM) broadly refers to the material flow stream of waste from generation to ultimate disposal, and comprises storage, collection, transportation/transfer, processing (reuse/recycling/composting), and disposal. Hence, inadequate SWM has resulted in the accumulation of solid waste on open lands, in drains, and in the living areas of many people [14]; causing a nuisance, and foul-smelling pools, environmental pollution through leachates from piles (which results in water and soil pollution), and burning of waste (resulting air pollution), clogging of drains, and the possible spread of diseases [15], especially in the poorer areas urban services are lacking even more. This situation is believed to result in an ever-present risk of epidemics, which in turn present formidable threats to health, and productivity [16]. 
Moreover, due to the lack of proper waste management, waste becomes a barrier in developing cities [17]. Henceforth, Dahiya [3] stated innovative methods of solid waste handling, disposal, and smart management [17] are important to reduce the amount of waste, and bring a sustainable solid waste management system for the city [5]. Hence, green architecture concepts provide a solution for the alarming growth of solid waste production accompanied by its poor management by the city of developing countries like Addis Ababa, Ethiopia.

In parts of Europe, North America, and Asia, the green architecture movement, which seeks to achieve a balance between the environmental, social, and economic performance of cities, and the buildings have gained momentum in recent years. Studies stated that one of the core ideas of green architecture is waste reduction and recycling. Green architecture strategies have focused on the amount of waste generated by the occupants, by providing on-site solutions, such as compost bins to reduce matter going to landfills [18]. Green architecture strategies, such as recycling, composting, waste minimization, etc., can save up to $70 \%$ of solid waste, $50 \%$ of energy use, $40 \%$ water use, and $35 \%$ of carbon emissions. On the contrary, developing countries have remained with a huge assignment regarding the adoption of green architecture strategies and concepts as better management approaches of solid wastes in urban areas.

Though the volume of solid waste generated in Africa is small compared to developed regions, less than half of the solid waste produced is collected, and 95 percent of that amount is either indiscriminately thrown away at various dumping sites on the periphery of urban centers, or at a number of so-called temporary sites, typically empty lots scattered throughout the city [19-21]. The rapid and high diplomatic, and industrial development of Ethiopia has attracted not only domestic and international companies, but also increasing population numbers of the city to support the growth. Addis Ababa has an estimated population of 3.43 million [22], is considered a major metropolitan city by any developing country standard. Population explosion and the associated anthropogenic activities generate huge amounts of different types of wastes that adversely affect the physical environment of the city. Solid waste, which is a consequence of day-to-day activities of society, needs to be managed properly. Addis Ababa, like other cities in developing countries, faces problems associated with poorly managed solid waste operations. While cities are generating an ever-increasing volume of waste, the effectiveness of their solid waste collection, and disposal systems are declining [19].

Similarly, despite the efforts of various governmental, nongovernmental, and civic societies, poorer solid waste management is the leading problem in Ethiopia. According to the existing management practices of MSW in the city of Addis Ababa, it is estimated that the solid waste generated rate is about $0.45 \mathrm{~kg}$ per capita per day, the average estimated density is $330 \mathrm{~kg} / \mathrm{m}^{3}$, and a total of approximately $6019 \mathrm{~m}^{3}$ solid waste is generated in the city. The estimated physical composition: Vegetables $4.2 \%$, paper $2.5 \%$, rubber/plastics $2.9 \%$, wood $2.3 \%$, bone $1.1 \%$, textiles $2.4 \%$, metals $0.9 \%$, glass $0.5 \%$, combustibles leaves $15.1 \%$, none combustible stones $2.5 \%$, and all fines (sand, ash, and dust) $65 \%$. The produced quantities of MSW are directed to an uncontrolled landfill, Koshe (Reppi), where it now lies within the heart of the city, and poses a serious health risk to its surrounding neighborhoods [23]. The compostable portion of the total generated waste would be used either for the sake of compost or generation of biofuel. The environmental pollution, due to solid waste, has continued to plague the city of Addis Ababa at an increasing speed, due to the dumping of solid waste from household, commercial, industrial sources, and other sources. The core problem is the pollution of the environment, especially on streets, rivers, ditches, and sewerage systems. Pollution increases the health risks of the people, and reduces the aesthetic value of the environment [24-26].

In Addis Ababa, a large proportion of the solid waste is left uncollected or disposed of in open spaces, ditches, and rivers. This is mostly due to insufficient waste collection techniques, and a lack of public awareness. The collection and disposal of solid waste is a persistent problem for the city. There are studies that confirm the existence of these 
problems widely. For instance, the study conducted in Addis Ababa implies there is the low performance of SWM [19]; solid waste disposal site impacts on groundwater and public health [27]; assessed the characteristics of solid waste generated at the household level and its level of impact on the environment [28]; focused on collection and disposal problems of solid waste [29]; assessment and evaluation of solid waste management strategy has been studied by Mohammed and Elias [30], and Pollution Status of the Solid Waste Disposal Site [31]. Hence, these and other study conducted in the city shows that there is poor management of solid waste in Addis Ababa. Seeing these and other studies, the study fills the gap by assessing the state of solid waste in Addis Ababa from 2016 to 2020 to shows the generation, collection, flow, and management of solid waste of Addis Ababa to provide implications for achieving green architecture concepts through better management of solid waste of the city.

\section{Materials and Methods}

Addis Ababa was established in 1886. It has an area of 540 square kilometers. It lies between 2000 and $3000 \mathrm{~m}$ above sea level. Despite its proximity to the equator, Addis Ababa enjoys a mild, Afro-Alpine temperate and warm temperate climate. The lowest and the highest annual average temperature are about $10{ }^{\circ} \mathrm{C}$ and $25^{\circ} \mathrm{C}$. Annual rainfall is around $1200 \mathrm{~mm}$. In the projection, however, we assumed Addis would grow in the same proportion as the overall urban population of the country [32].

Addis Ababa is the capital city of the country with great geographical diversity endowed with rich natural and human resource base. To undergo its administration activities, Addis Ababa is divided into 10 subcities, and 99 Districts (Table 1; Figure 1).

To conduct the study, data on generation, collection, composition, exiting management system, and environmental problems are required. Therefore, these data were collected mainly from secondary sources and primary sources. The source for the secondary data were both published and unpublished materials-from City Government of Addis Ababa Solid Waste Management Agency and IGNIS. Moreover, books, journals, research works, government policy, and strategies in relation to the issue under consideration were reviewed. Furthermore, data from CSA and City Government of Addis Ababa Urban Planning and Information Institute were utilized to prepare the map. On the other hand, sources for primary data were personal observation, which was conducted at a different site, such as communal garbage, Reppi dumping site, and streets. A semi-structured interview with two experts of the City Government of Addis Ababa Solid Waste Management Agency was done. Moreover, data about the amount of solid waste generated and collected from 2016 to 2020 were collected from Addis Ababa Solid Waste Management Agency.

Table 1. Characteristics of the ten subcities of Addis Ababa.

\begin{tabular}{ccccc}
\hline Name of the Subcity & Population (2007) $^{\mathbf{1}}$ & Subcity Area (ha) $^{\mathbf{2}}$ & Number of Districts & Population Density (pop/ha) \\
\hline Arada & 212,129 & 950 & 10 & 223 \\
Addis Ketema & 254,975 & 864 & 9 & 295 \\
Lideta & 201,613 & 918 & 9 & 220 \\
Kirkos & 220,991 & 1465 & 11 & 151 \\
Bole & 308,714 & 11,847 & 11 & 26 \\
Nifas silk-lafto & 315,134 & 5876 & 10 & 42 \\
Yeka & 345,807 & 8213 & 8 & 15 \\
Akaki-kality & 183,288 & 12,345 & 10 & 67 \\
Kolfekeranio & 428,219 & 6349 & 10 & 86 \\
Gulele & 267,381 & 3119 & \\
\hline
\end{tabular}

Source: ${ }^{1}$ Central Statistic Agency of Ethiopia 2008 and ${ }^{2}$ City Government of Addis Ababa 2012 


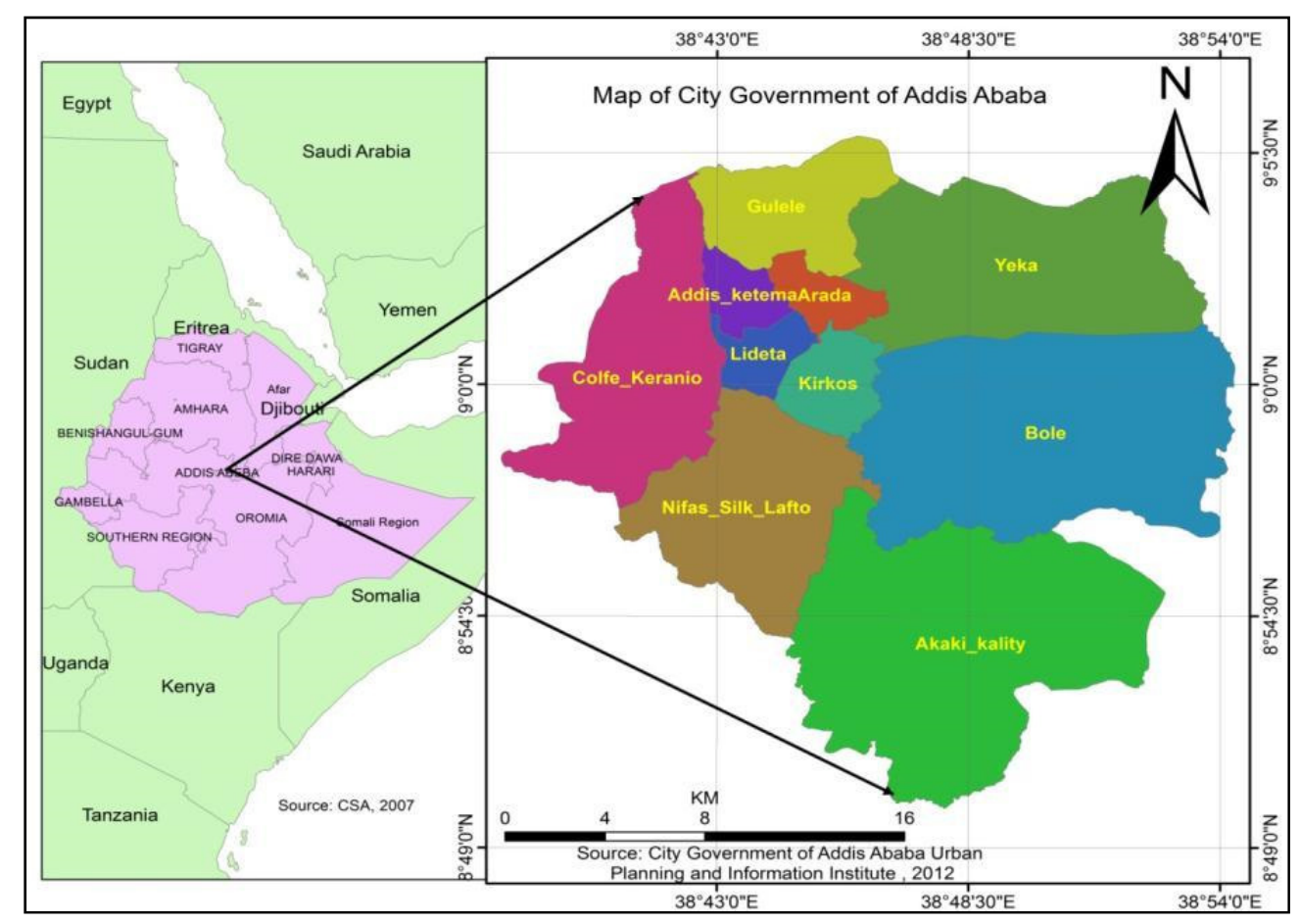

Figure 1. Map of Addis Ababa by subcities.

The data was collected from the secondary source about the generation and collection of solid waste was presented using percentages and analyzed through mean and standard deviation. Geo-referenced data were analyzed using GIS software (ArcGIS10.3) to prepare a map of the study area. The narration was done to analyze the data collected through interviews and observation. The analyzed data were presented through tables, pie charts, bar graphs, and line graphs.

\section{Results and Discussion}

\subsection{Generated and Collected Solid Wastes at Addis Ababa}

According to Addis Ababa Solid Waste Management Agency, solid wastes have been generated from households, commercial centers, street sweeping, industries, hotels, and hospitals. Table 2 shows solid wastes generation and collection of Addis Ababa during 20162020 were calculated. Hence, the table shows that more than 3.2 million $\mathrm{M}^{3} ; 3.1$ million $\mathrm{M}^{3}$; 3.5 million $\mathrm{M}^{3}$, 3.7 million $\mathrm{M}^{3}$, and 1.1 million $\mathrm{M}^{3}$ of solid waste are generated in 2016, $2017,2018,2019$, and 2020, respectively. For the city, there is no up-to-date and reliable data regarding the solid waste generation rate. There are few studies undertaken since 1982 by different bodies. Nur consult carried out the first main study in 1982. The result suggested that per capita generation of solid waste was $0.15 \mathrm{~kg} /$ day /person with a $1 \%$ annual growth rate and approximate waste density of $370 \mathrm{~kg} / \mathrm{m}^{3}$ [33].

Table 2. Solid wastes generation during 2016-2020.

\begin{tabular}{cc}
\hline Year & Generation $\mathbf{( M}^{\mathbf{3}} \mathbf{)}$ \\
\hline 2016 & $3,181,705$ \\
2017 & $3,143,380$ \\
2018 & $3,523,710$ \\
2019 & $3,701,100$ \\
2020 & $1,116,340$ \\
total & $14,666,235$ \\
\hline
\end{tabular}


On the other hand, Louise Burger international, in 1986, carried out the second study, and the per capita generation result was $0.20 \mathrm{~kg} /$ day/person. Louise Burger international also carried out the third available study in 1994 and 1995. According to the 1994 study, the average per capita generation of solid waste was $0.22 \mathrm{~kg} /$ day/person, and the density is about $336 \mathrm{~kg} / \mathrm{m}^{3}$. The 1994 and 1995 study shows as the generation of solid waste varies depending on the income levels of the generator. Based on the data collected in 1994, generation/capital/day was $0.35 \mathrm{~kg}, 0.28 \mathrm{~kg}$, and $0.17 \mathrm{~kg}$, for high, medium, low-income groups, respectively. The data of 1995 collected shows $0.47 \mathrm{~kg}, 0.236 \mathrm{~kg}$, and $0.26 \mathrm{~kg}$ for high, medium, and low, respectively [29]. This implies the emphasis that was given for the solid waste study, and management is very low from the city administration, unlike any other sector. In this study, it is observed that the generated solid waste has been increasing from time to time (Table 2). In line with this, Bello et al. [34] stated in Africa, there is an increase in the generation of both domestic and industrial waste, due to an increase in consumption rate that has a direct effect on it. Eastern and Western Africa, are the two most rapidly urbanizing subregions in Africa. As the population grows and urbanization increases, as does the amount of waste. In 2015 the annual waste generation for urban Africa was 124 million tons [35]. However, due to the occurrence of COVID-19 at the beginning of 2020, most of the activities are limited, and a shutdown was there. In line with this, Sarkodie and Owusu [36] stated limitations on commercial activities, mobility, and manufacturing sector have significantly affected waste generation and its management, due to the containment of the spread of the COVID-19 pandemic. On the other hand, there is a likelihood of the generation of solid because of the increased consumption with increased accumulation, due to working from home and possibly limited collection rate by the agency [37].

Having data on waste generators provides an insight that helps to improve the sustainability of waste management. Hence, the share of the solid waste generation, the annual generation of solid waste in Addis Ababa by sources from 2016 to 2020 in $\mathrm{M}^{3}$, has been calculated. Figure 2 indicates that $71 \%$ of the solid wastes are generated from the households, followed by street sweeping (10\%), commercial centers (9\%), industries / factories $(6 \%)$, hotels (3\%), and hospitals (1\%), respectively [33]. This implies that the government has to work closely with the household for the proper and effective management of solid waste from its source. Knowing the major contributor helps to plan about access to finance and proper technical knowledge to go a long way in assisting the waste management with the municipalities who are most times ill-equipped to deal with prompt collection and disposal of waste [34]. Figure 2 indicated that in Addis Ababa, the major generator of solid waste is household-thus, the intervention for the application of integrated solid waste management and the concept of green architecture can be applied.

\subsection{Collection Solid Waste at Addis Ababa}

The solid waste has to be collected because according to Environmental pollution control proclamation No. 300/2002: Article 5(1); Management of Municipal Waste: "All Urban Administrations shall ensure the collection, transportation and as appropriate, the recycling, treatment or safe disposal of municipal waste through the institution of an integrated municipal waste management system". Moreover, solid waste management proclamation No. 513/2007: Article 4(1); "Urban Administrations shall create enabling conditions to promote investment on the provision of solid waste management services." Hence, in Addis Ababa, solid waste has been collected by different institutions. The data collected from Addis Ababa City Solid Waste Management Agency [33] shows there is an increase in generation, as well as collection capacity, except for 2020 (Figure 3). However, it is shown that the generation of solid waste surpasses the collection. The uncollected solid waste has left and an implication on its management that has directly impacted the health of the people and environment surrounding [38]. 


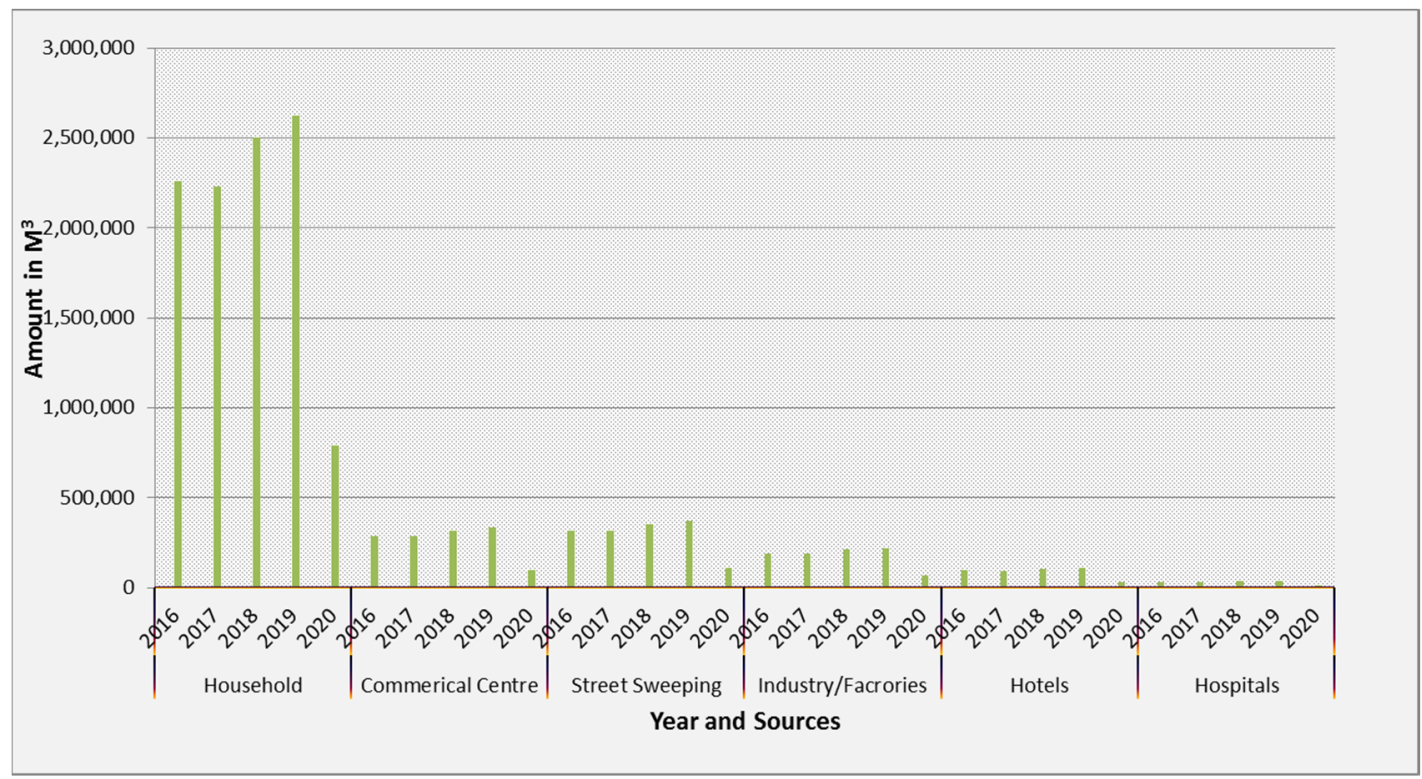

Figure 2. The generation of solid waste in Addis Ababa (2016-2020) ( $\left.\mathrm{M}^{3}\right)$.

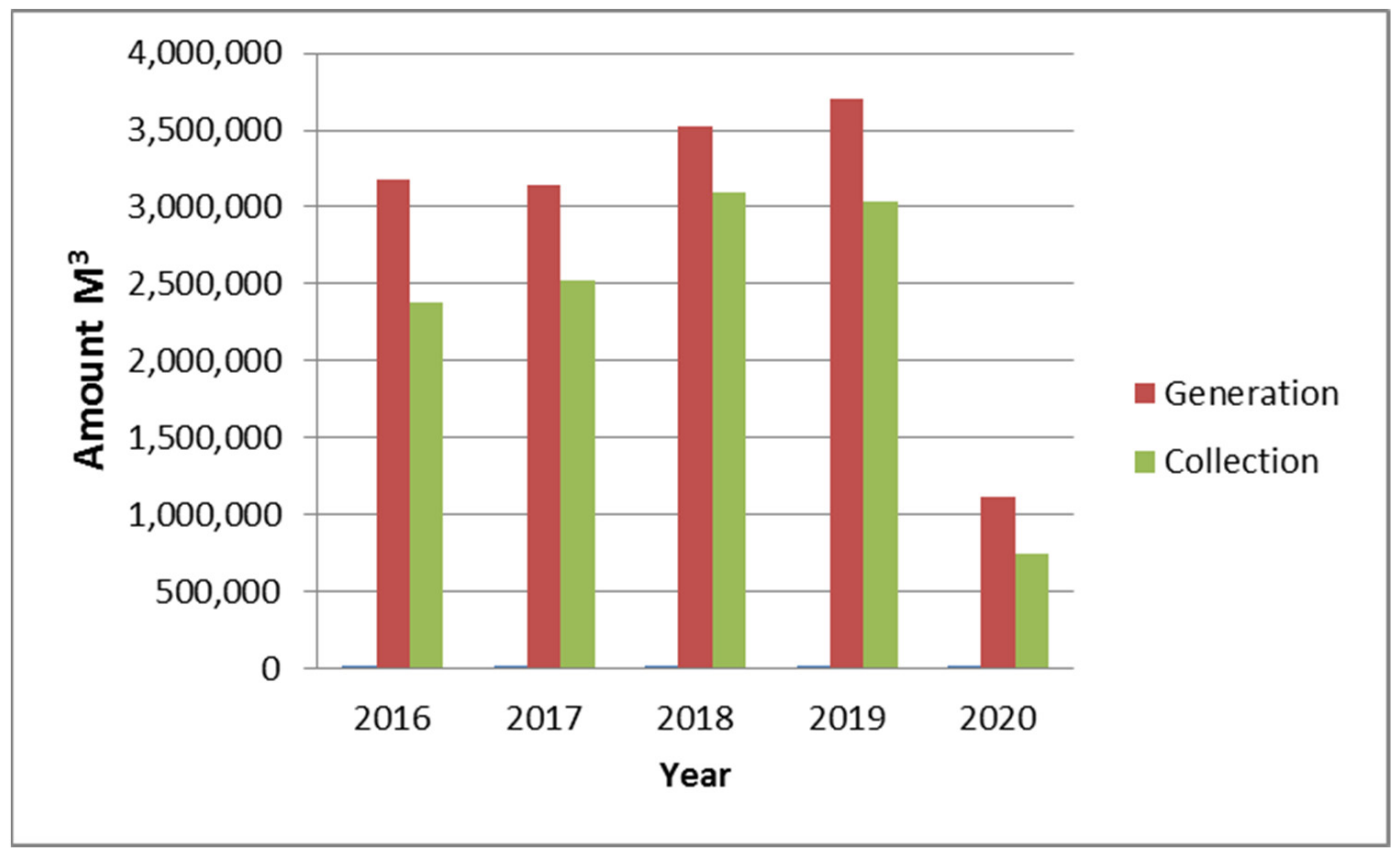

Figure 3. Generated and collected solid waste in Addis Ababa during 2016-2020 in $\mathrm{M}^{3}$ (Sources: AASWMA 2020).

Generally, most of the collected solid waste at Addis Ababa is directly disposed of to the Reppi open landfill site without any segregation [33]. Similarly, van Niekerk and Weghmann [35] stated in Africa, open dumping is by far the most common one, which open dumping in this context refers to the unplanned dumping of waste without the involvement of environmental protection mechanisms. Hence, this kind of disposal has a negative impact on both the community and the environment. Similarly, in Addis Ababa, Reppi is the only landfill site that has served the city since 1964. In line with this, van Niekerk and Weghmann [35] stated many cities in Africa have only one official landfill site for the whole city, which in many cases is overflowing and a serious health and safety concern. For instance, in Abidjan, Ivory Coast, the only existing landfill site for many years was Akouedo (constructed in 1965). 
The flow of solid waste from Addis Ababa to the open landfill site is increasing from time to time in amount and types. Since the waste is dumped without any segregation, these invite many selvages (waste pickers) to go in and search for reusable and recyclable materials from the site. Likewise, this landfill has brought some social problems like odor and environmental problems (Figure 4).
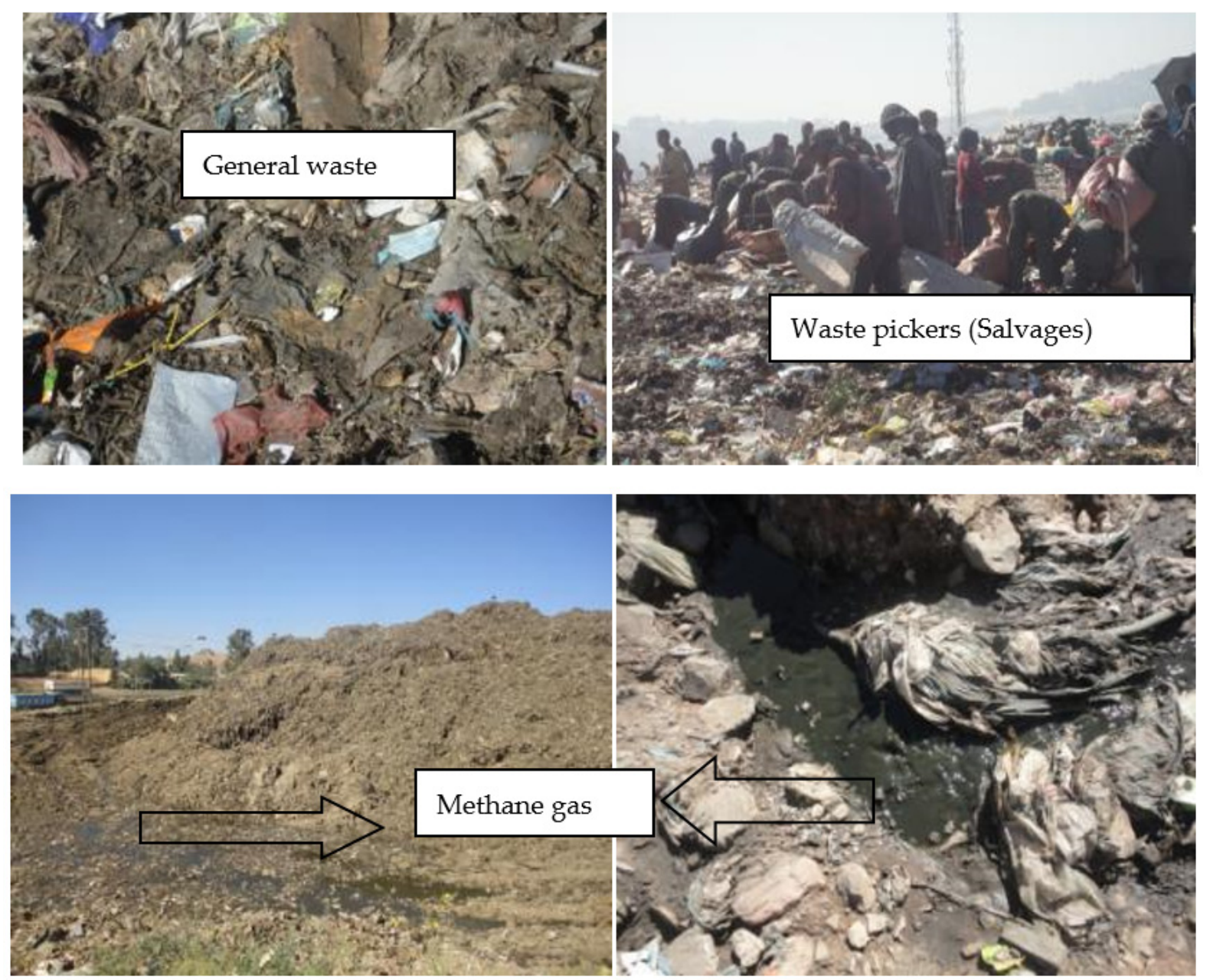

Figure 4. Reppi open landfill site.

According to the experts of Addis Ababa Solid Waste Management Agency, in the city, the formal waste management sector is characterized by the primary collection, carried out mainly by pre-collector associations, the secondary collection, and final disposal, mostly carried out by the government, and few SMEs. Similarly, a study conducted in Bangladesh [39], Mozambique [40], and Nigeria [41] showed that, like most developing countries, waste is collected from generation sources, and transferred to ultimate disposal sites (landfill).

In Addis Ababa, there are different actors involved in the collection, transporting, and disposal activities in the city's solid waste management. For this, the agency has a work process in all subcities and all districts to control the collection, and disposal of solid waste of the subcities and districts. The agency mainly engaged in collecting solid waste generated on the street, and transporting the collected solid waste to the landfill. Hence, the agency has given solid waste collection and transportation services for private organizations, and SMEs to collect solid waste that is generated by different service provides (NGOs and private sectors), and households, respectively. However, the services provided by these organizations are not enough to fully collect the waste generated in the city. Similarly, in developing countries, cities have failed to fully implement the ISWM strategies at their 
full capacity. However, in the major cities, developing literature shows there has been an attempt, but rapid urbanization, population growth, increasing consumption, and way of life makes the application of ISWM difficult [11,40-42].

According to Addis Ababa Solid Waste Management Agency, the solid waste collection service provision is structurally stretched into three layers at the city level. The agency at the top, 10 subcity administrations in the middle, and each district at the bottom are structurally in place to improve the solid waste management systems. However, the agency is collecting and transporting mixed solid waste from a different point of generation. Moreover, the agency encourages private organizations to collect and dispose the solid wastes from different institutions. Hence, there are 161 private vehicles engaged in transporting waste to the Reppi landfill.

According to an expert from Addis Ababa Solid Waste Management Agency, there are three modes of collection systems; communal container collection using the lift and compacting trucks, institutional collection using lift trucks, and door to door collection using compactor and side loader truck. It is also mentioned by the expert as each subcity is responsible for transporting solid waste to the final landfill Reppi using trucks. According to the interview held with the expert from the agency, currently, there are 119 trucks. The main challenge of the trucks is that they are very old, maintenance difficulties, negligence of drivers, and frequent accidents. The vehicles carry only a single container at a time to the disposal site with a maximum capacity of $8 \mathrm{M}^{3}$, and side loaders carry $10 \mathrm{M}^{3}$.

\subsection{Primary Collection and Accumulation}

The formal waste management sector is characterized by primary collection, carried out mainly by pre-collector associations. Pre-collectors are in charge of collecting waste from door to door, which is then transported by pushcarts to the skipping points where the waste is transferred to containers, or directly to waste compacting vehicles. In the city, there are 87 Small and Micro Enterprises (SMEs), and 53 private companies that collect solid wastes. Moreover, street waste is collected by street sweepers. The sweepers/cleaners sweep the roads and clean the drains manually, and debris is loaded from the curb-side into the handcarts, then places those wastes in the nearby dustbins or containers using a handcart (Addis Ababa Solid Waste Management Agency, 2020)

Collections of solid waste from households and small commercial centers have been done by SMEs of each District. It is assumed that each SME collects solid waste from 600-1050 households. Each SME gives at least 2-3 days a week collection service within every household and every day from small commercial centers using pushcarts. All the collected waste is accumulated in detachable garbage containers and nearby roads then container lifter car and side loader car, respectively, arrive and load the collected solid wastes and disposed to Reppi open landfill (Figure 5). Since the service provided by SMEs does not meet the demands of private organizations that have been encouraged to collect solid waste from large commercial centers and organizations, and they are directly disposed to the Reppi open landfill. 

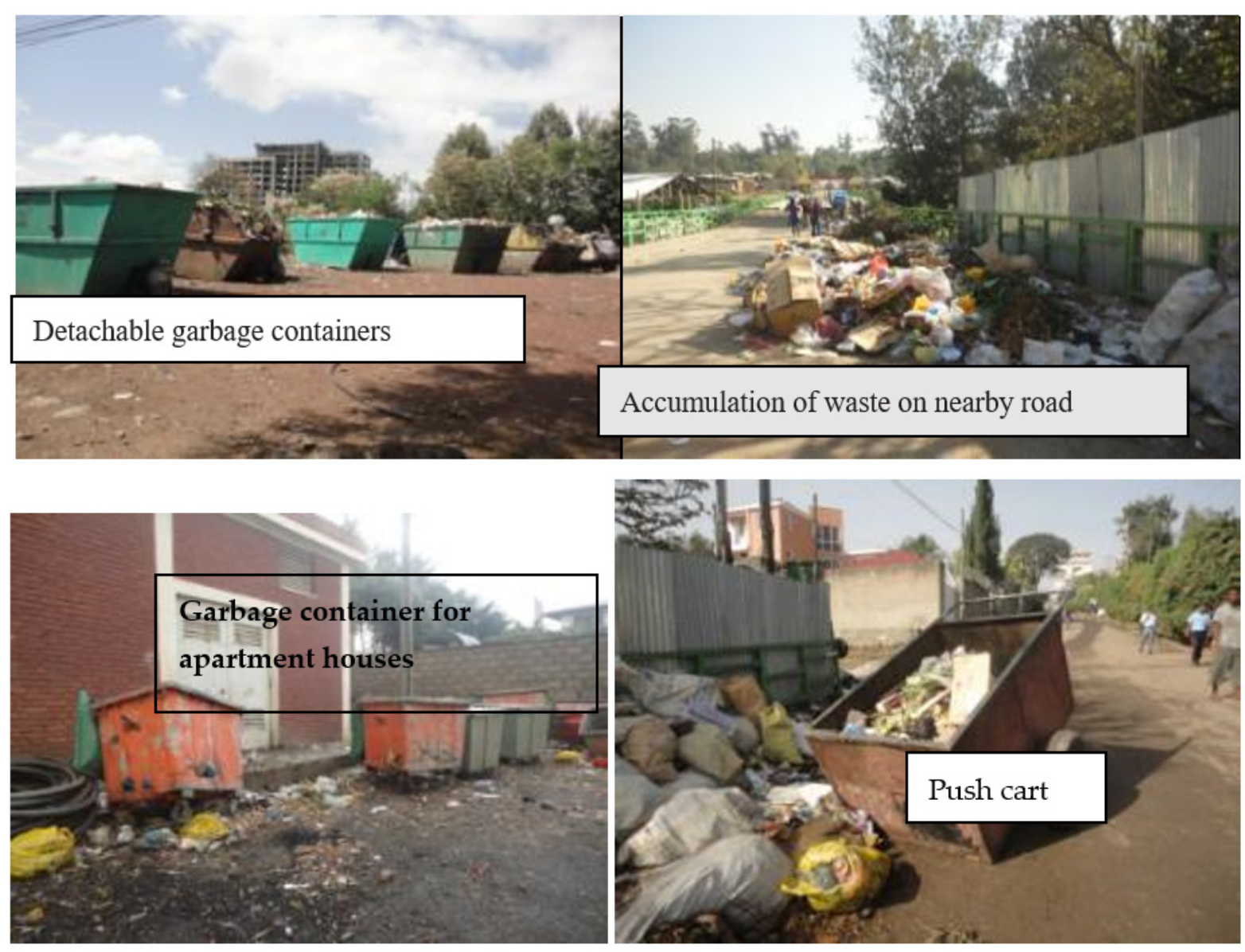

Figure 5. Primary collection and accumulation from households and small commercial centers.

\subsection{Secondary Collection}

The solid waste management agency is mainly involved in the secondary collection, landfill management, and to some extent, the private sectors are also involved in the secondary collection. Moreover, the subcities play a major role in the secondary collection and transportation of waste from communal containers and transfer sites to the Reppi disposal site. The subcity also does dispatching and monitoring the transportation system and maintenance of trucks. Of which vehicles most of them have the age more than 10 years. The experts from the Solid Waste Management Agency explained most of the vehicles are very old, and some of them are not functional until they get maintenance. Hence, of the collected solid waste, $57 \%$ is transported by the government, $21 \%$ by private sectors, and $22 \%$ outsources.

\subsection{Opportunities and Challenges of Solid Waste Management in Addis Ababa \\ 3.5.1. Solid Waste-to-Energy}

According to the expert of Addis Ababa Solid Waste Management Agency, there are attempts that have been made to increase the collection capacity of the solid wastes by applying different techniques of the integrated solid waste management system (ISWM), but due to awareness, the unattractiveness of the sector of solid waste collection and scarcity of professional in the field make the collection rate and application of different technology is very slow. Furthermore, the official of Addis Ababa Solid Waste Management Agency mentioned that all the collected waste is disposed to the open landfill site Reppi without any segregation. However, since 2019 after reclaiming 19 Hectares of Reppi waste site, energy has been produced from waste though the plan was to produce 50 MWh energy per day, but now the Rappi waste-to-energy production takes, on average, 600 tons of waste per day for the energy production, which is below the planned capacity, which is 
1400 ton/day. Figure 6 shows the monthly production of waste-to-energy. The figure shows, on average, the Rappi waste-to-energy strategy produces 15.7 MWh energy.

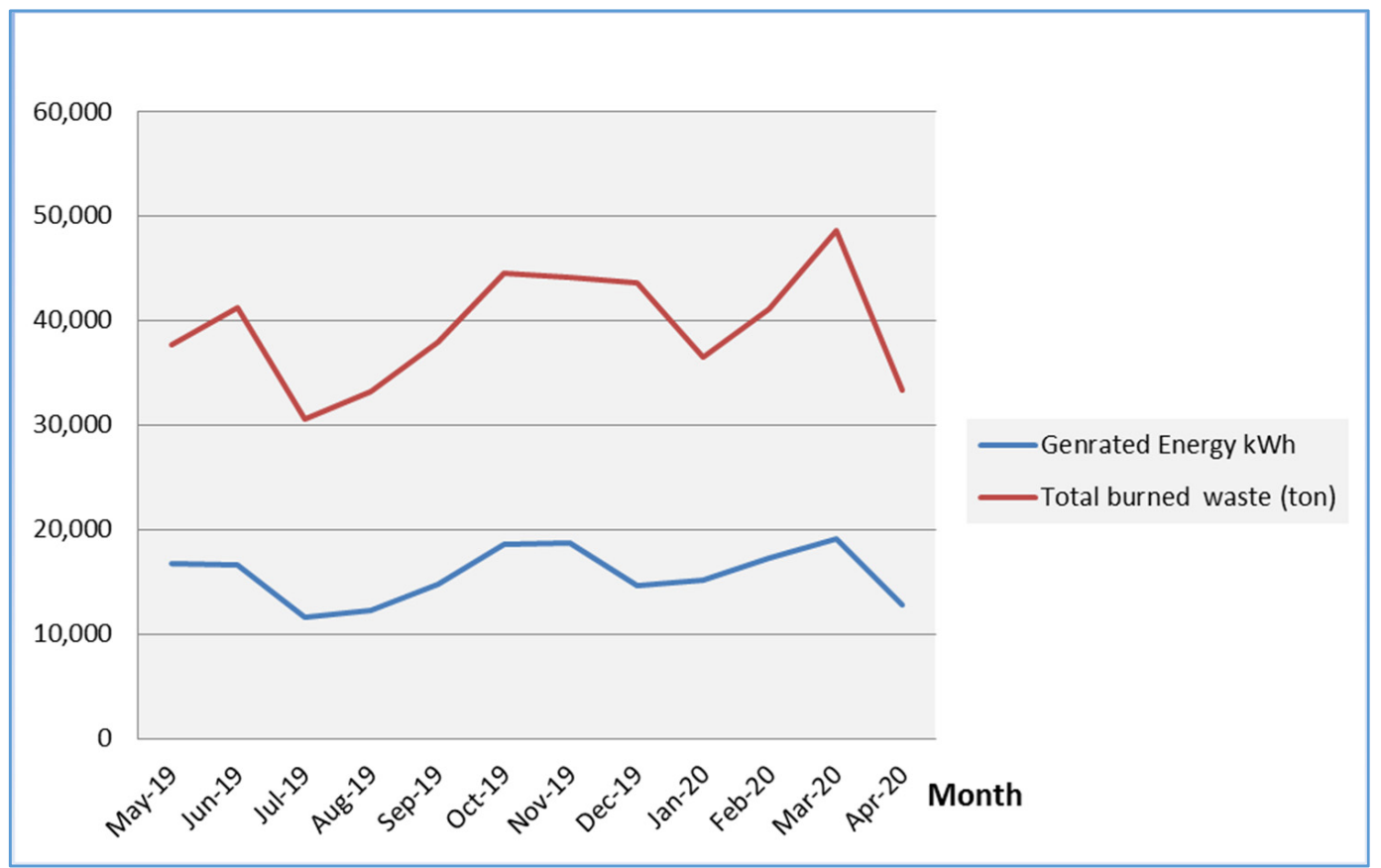

Figure 6. Waste-to-energy production (source AASWMA, 2020).

\subsubsection{Composting}

In Addis Ababa, $74.29 \%$ of the household waste was biodegradable organic, $17.41 \%$ of it was recyclable, and the rest $8.27 \%$ was potentially hazardous waste [33]. Hence, there is composting program that has been started in 2020, for as input, the waste from the city's largest vegetable, and fruit market, which is located around the Nifasilk subcity, has been collected and provided. Hence, from its date of start in November 2020 to February 2020, $326,240 \mathrm{~kg}$ waste was delivered for 104 cooperatives for the production of compost. As Ayilara et al. [43] stated, composting transforms degradable wastes into products that can be used as bio-fertilizers. Furthermore, it is environmentally friendly because the process of composing protects underground water from being polluted compared to landfilling methods of waste disposal. Similarly, the study conducted by Trivedi et al. [44] in India encouraged organic composting technology must be encouraged for effective solid waste management by reducing reduces disposed garbage quantity. This implies one of the strategies to reduce municipal solid waste is encouraging private and NGOs to engage in composting programs to use $74 \%$ of the biodegradable waste that is generated in the city. This has the ultimate impact in reducing the solid waste that goes to the Reppi landfill. Another study conducted in developing countries also shows that $50 \%$ of the solid waste generated in these countries is composed of organic waste that can be biodegradable, and it is suggested that a viable option for managing this waste is composting [45].

\subsubsection{Greenery Practice in the Reclaimed Site of Reppi}

The Reppi open landfill covers a surface area of 37 hectares and $40 \mathrm{~m}$ deep it is one of the largest single concentrations of waste in Addis Ababa. Around 19 hectares of Reppi open landfill site is close, due to the plan to generate energy from the waste. Hence, in the area, it is observed that there are physical and biological conservation works. The physical work is terracing, followed by the biological work, such as plantation of trees like Juniperus procera, Grevillea robusta, Neem (Azadirachta indica), and others. Moreover, it is observed that there is a nursery site to produce seedlings for the plantation that is planted 
on the reclaimed site. The nursery site uses compost that is prepared from the dumping site (Figure 7).

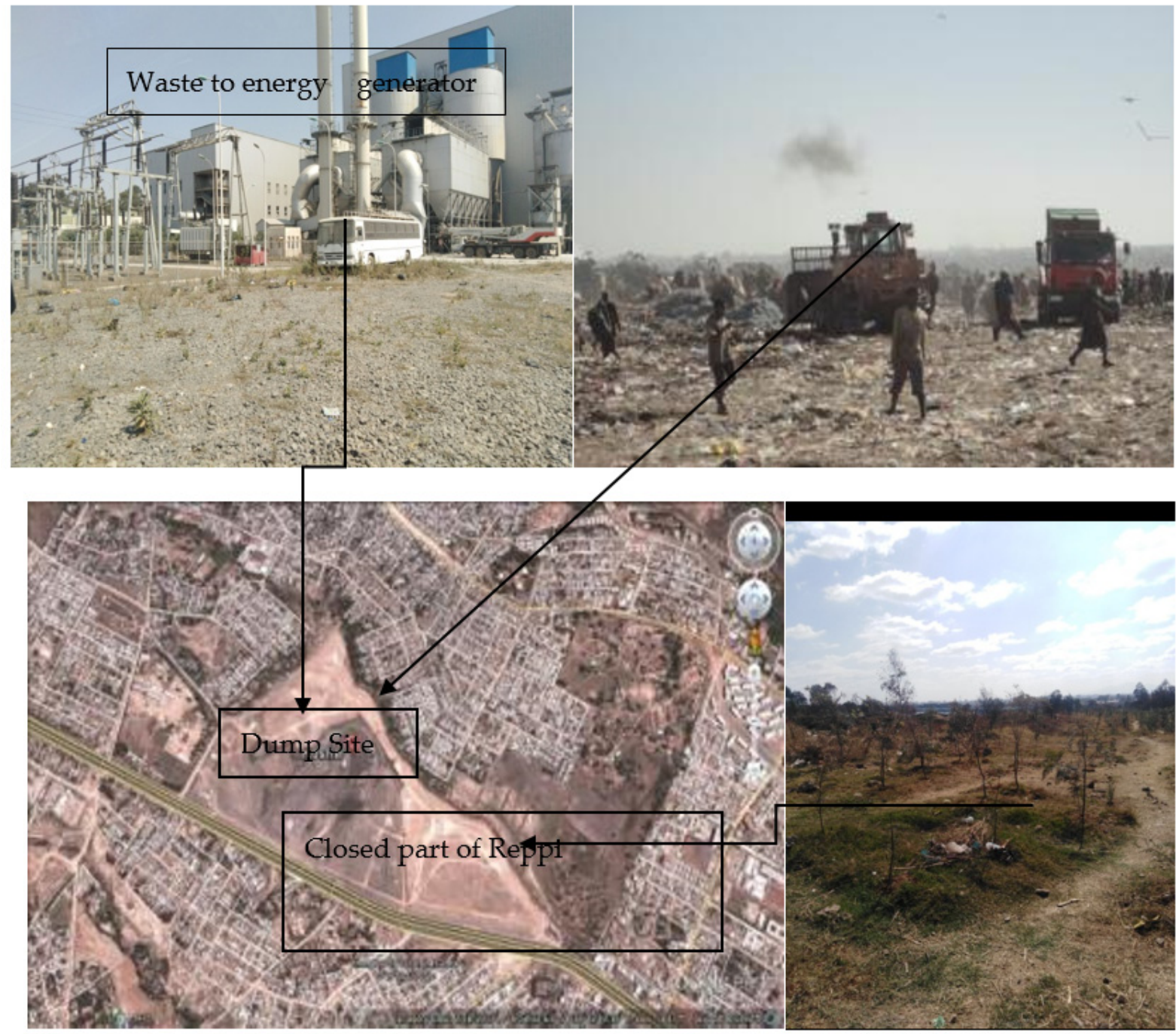

Figure 7. Landfill and reclaimed part of Reppi (Source: Google Earth 2020).

\subsubsection{Employment Opportunities}

According to the Solid Waste Management Agency, solid waste has created employment opportunities for 87 SMEs for collecting solid waste from households and for $104 \mathrm{co}-$ operatives for the production of compost. Besides, it is estimated that there is an average of 1500 waste pickers in the Reppi landfill site whose lives depend on picking useful resources from incoming solid waste. Waste pickers have also employed compost production and seedling preparation in the nursery site (Figure 8). According to Sharma et al. [17] unemployment and waste management are the big problems in urban areas. Hence, create awareness about developing and creating employment opportunities for skilled and unskilled workforce by showing the ways and techniques of proper waste management are important to reduce the two urban problems. However, there are studies conducted in several countries have shown that some workers are employed by informal businesses [46]. 

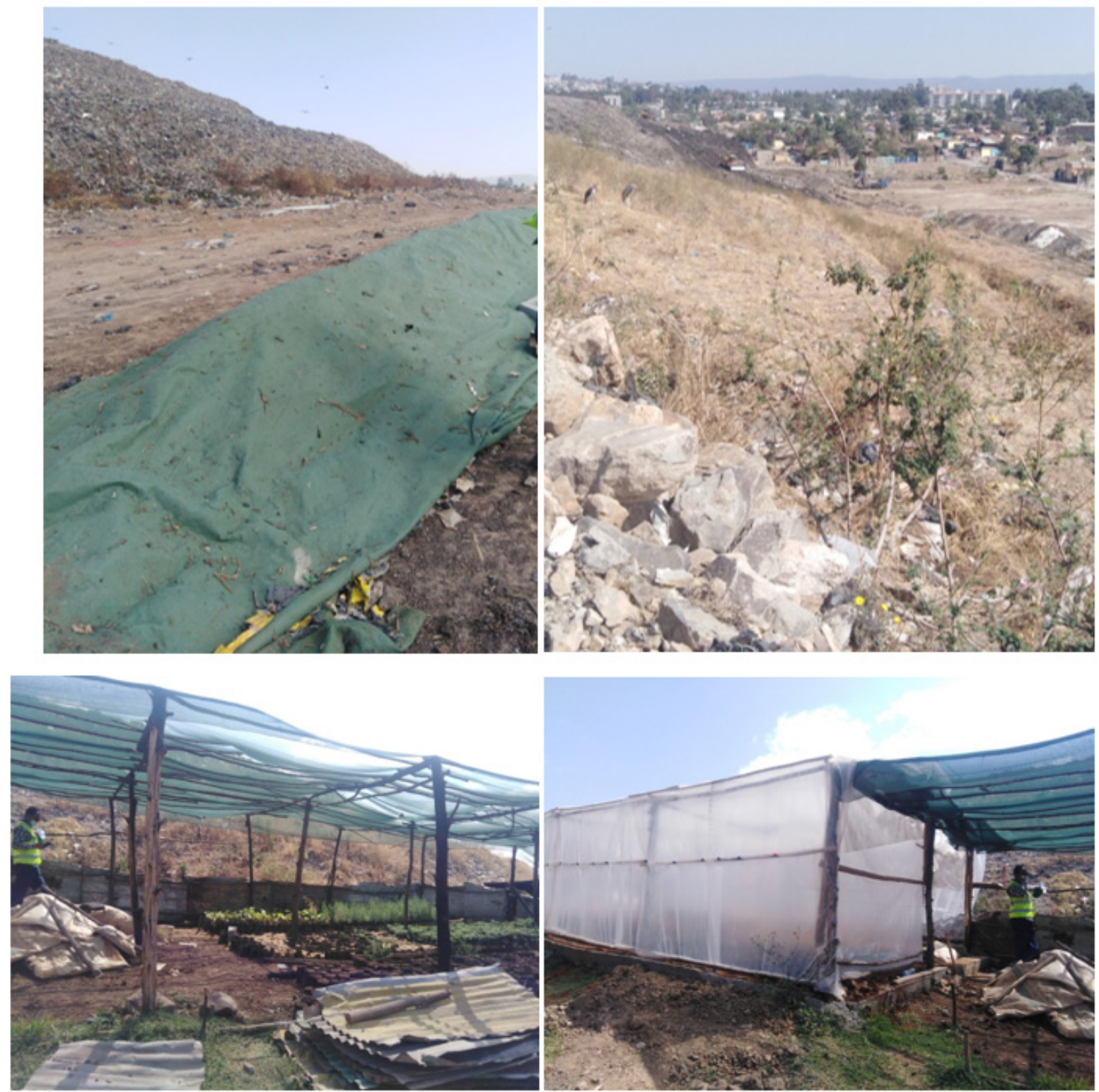

Figure 8. Reppi Nursery and next plantation site, 2021.

\subsection{Challenges in the Management of Solid Waste in Addis Ababa}

Experts have been asked about the challenges related to the solid waste management of the city. They explained that less emphasis is given by the government in including the policy and planning, lack of space to perform different activities related to solid waste. For instance, there were attempts to have three transfer stations before the waste is transferred to the landfill. However, due to financial scarcity and less attention by the city government, the attempts have failed. The other challenge is most of the government tracks are out of service, less attractiveness for the private sector, and lack of skilled human resources in the area. There is also a limitation in the development and implementation of the project. According to Guerrero et al. [47], high generation, budget, lack of cross-sectorial linkage, and handling system are challenges for the proper management of solid waste in many developing countries. Inadequate supply of waste facilities [15], number of vehicles for waste collection [48], and lack of safe disposal of waste, absence of well-equipped and engineered landfills, and implementation of legislation [49] are also the challenges that the solid waste management sector. 


\subsection{Implications for Achieving Green Architecture Concepts through Solid Waste Management Practice}

Based on insights gained from the findings of this study, literature, key informant interviews, and field observations, the following implications are made to achieve green architecture concepts through solid waste management practices in Addis Ababa, in particular, and in the country in general.

First of all, it is really important to minimize the amount of waste generated. As the result of the study shows, the increasing amount of waste affecting all aspects of life in the city. The average municipal waste produced in the city is approximately $0.15 \mathrm{~kg} /$ day / person with a $1 \%$ annual growth rate and approximate waste density of $370 \mathrm{~kg} / \mathrm{m}^{3}$. Problems associated with waste include the energy and transport impacts of transferring materials and the environmental impacts associated with the disposal methods. Waste minimization can help to reduce these disposal impacts, and by recycling waste, less new material is required, so waste minimization can also help to reduce the impacts associated with material production. Waste minimization can contribute to the achievement of green architecture concepts in the city, since one of the strategies of green architecture is waste minimization. A key consideration for effectively minimizing waste is knowing the types of materials that make up the bulk of that waste, and then finding ways to use them more efficiently, or not at all.

Secondly, waste reuse is recommended as the best solid waste management option after waste reduction for achieving the concepts of green architecture in the city. Our results show that in the city, it is important to develop the practice of reusing materials. Some common examples include donating used household items like books, magazines, clothing, kitchen wares, etc. It may also include using empty food containers to store leftovers or reusing plastic grocery sacks to line trash containers or pick up after pets. Studies also show that waste reuse can achieve the objective of green architecture, which is minimizing adverse environmental, social, and economic impacts of buildings [50,51].

Thirdly, encouraging composting practices in the city is also important. In the study area, there should be a need for innovative solid waste management that can contribute to the achievement of green architecture concepts is very urgent. In this regard, composting is an important approach. It is a process of transforming potential biodegradable 1 organic waste fractions into useful products, such as compost. Hence, composting, as the sustainable transformation of potential organic wastes tunes up with sustainable waste management, must be optimized and encouraged. Because solid wastes in developing countries are composed of over $50 \%$ organic materials [52]. Open burning of such waste is a waste of time, whereas disposal in landfills will waste resources. The viable option to sustainably manages wastes in developing nations is composting because of the following advantages: Lower operational cost Airan and Bell [53], decreased water pollution, reduce environmental pollution, and beneficial use of end products [54]. Cointreau [54] found that in developing nations, such as Indonesia, Colombo, and Sri Lanka, residential wastes are 78,81 , and $89 \%$ compostable, respectively. Therefore, in the study area, even though the composting project had also started in 2020, it is not fully utilized, and it is not planned in a way that it can achieve the concepts of green architecture in the city. Hence, in the study area, it is important to encourage composting practices by giving due consideration to the concepts of green architecture.

Fourthly, based on information obtained from the literature, key informant interviews, and field observations, waste recycling has been identified as the best solid waste management strategy to achieve green architecture concepts in the city. The result of the study shows that there is little work on how to recycle solid waste. Studies found that waste recycling is the best way to achieve sustainable architecture [51-57]. Therefore, to achieve the concept of sustainable/green architecture in the city through better management of solid waste, the practices of converting waste materials into new materials, and objects should be encouraged. 
Fifthly, Waste-to-energy has also been recommended as the best strategy to achieve the concepts of green architecture in the study area. One of the aims of green architecture is energy efficiency [58]; therefore, covering waste-to-energy production can achieve the concepts and principles of green architecture. So, green architecture requires a sustainable supply of clean and affordable renewable energy sources that do not cause negative societal impacts. Energy sources, such as solar radiation, the winds, waves, and tides, are generally considered renewable, and therefore, sustainable over the relatively long term. Wastes and biomass fuels are usually viewed as sustainable energy sources. Wastes are convertible to useful energy forms like hydrogen (biohydrogen), biogas, and bioalcohol through wasteto-energy technologies. Based on the result of the study, the city government has been converting waste-to-energy since 2019, but based on the result of this study, the technology is not operated at its full capacity. Therefore, it is important to diversify this sector to achieve the concept of green architecture through better management of solid waste in the study area.

Finally, well-designed buildings have been recommended as the best strategy to achieve the concepts of green architecture through better solid waste management in the study area. Green architecture also seeks to reduce waste of energy, water, and materials used during construction. During the construction phase, one goal should be to reduce the amount of material going to landfills. Well-designed buildings also help reduce the amount of waste generated by the occupants as well, by providing on-site solutions, such as compost bins to reduce matter going to landfills. Building design can also encourage the recycling of domestic or commercial waste by providing appropriate recycling facilities in the building.

\section{Conclusions}

Environmental pollution, due to solid waste, has continued to plague the city of Addis Ababa at an increasing speed, due to the dumping of solid waste from household, commercial, and industrial sources. In the city, both the collected and disposed of solid waste have environmental and social impacts. Since 1964, the collected waste of the city is dumped in Reppi, which is now surrounded by residential houses and found next to the main road. The landfill has both positive and negative impacts. As observed in this study, some people pick valuable wastes from it, and they make money for living, but due to its age. On the other hand, and accumulation of mixed wastes for the last 50 years created bad odor, unpleasant vision, and litter. Furthermore, the inefficient solid waste management by the municipality increase accumulation of waste on open lands, and in the open drainage system causing environmental pollution through leaches from piles (water and soil), and the burning of waste (air pollution), which affects people's health. Moreover, due to its social and environmental impact, part of the current landfill (19 of the total 37 hectares) has been closed. Repii can generate $50 \mathrm{MWh}$ thermal output every hour, but currently averages 15.7 MWh, due to mechanical and technical issues.

Hence, developing meaningful partnerships with the private sector, informal workers, and communities for effective implementation of integrated solid waste management and 3Rs (reduce, reuse, and recycle); enforcing policy and regulation by concerned government organizations; creating awareness for the community at different levels and for all organization that generates solid waste to buy materials that serve long and materials that are reused and recycled; and identifying key stakeholders to have a sustainable solid waste management strategies to convert the solid waste into useful resources are important for efficient, and effective management of solid wastes that are generated from different sources.

Achieving the concept of green architecture in the city will require an effective integrated solid waste management and 3Rs practices (reduce, reuse, and recycle) in the city. Moreover, the practice of composting, waste-to-energy, and well-designed building are mandatory. 
Funding: This research received no external funding.

Institutional Review Board Statement: Not applicable.

Informed Consent Statement: Not applicable.

Data Availability Statement: Data is contained within the article.

Acknowledgments: We are indebted to Addis Ababa Solid Waste Management Agency for providing valuable data for this study.

Conflicts of Interest: The authors declare no conflict of interest.

\section{References}

1. Agwu, M.O. Issues and Challenges of Solid Waste Management Practices in Port-Harcourt City, Nigeria-A Behavioural Perspective. Am. J. Soc. Manag. Sci. 2012, 3, 83-92. [CrossRef]

2. USEPA. Solid Waste Management: A Local Challenge with Global Impacts. USA. 2002. Available online: www.epa.gov/ globalwarming (accessed on 29 January 2021).

3. Dahiya, R. Projections for the Population Growth and Its Impact on Solid Waste Generation of a Medium Sized North Indian City. Int. J. Tech. Res. Appl. 2015, 3, 57-61.

4. John, S. Sustainability-based decision-support system for solid waste management. Int. J. Environ. Waste Manag. 2010, 6, 41-50. [CrossRef]

5. Liu, J.; Li, Q.; Gu, W.; Wang, C. The Impact of consumption patterns on the generation of municipal solid waste in China: Evidences from provincial data. Int. J. Environ. Res. Public Health 2019, 16, 1717. [CrossRef] [PubMed]

6. Afolayan, O.S.; Ogundele, F.O.; Odewumi, S.G. Hydrological Implication of Solid Waste Disposal on Groundwater Quality in Urbanized Area of Lagos State, Nigeria. Int. J. Appl. Sci. Technol. 2012, 2, 5.

7. Chen, H.; Dou, J.; Xu, H. Remediation of $\mathrm{Cr}$ (VI)-contaminated soil with co-composting of three different biomass solid wastes. J. Soils Sediments 2018, 18, 897-905. [CrossRef]

8. Momodu, N.S.; Dimuna, K.O.; Dimuna, J.E. Mitigating the impact of solid wastes in urban centres in Nigeria. J. Hum. Ecol. 2011, 34, 125-133. [CrossRef]

9. Tadesse, T. Solid Waste Management. Produced in Collaboration with the Ethiopia Public Health Training Initiative, The Carter Center, the Ethiopia Ministry of Health, and the Ethiopia Ministry of Education; Gondor University: Gondar, Ethiopia, 2004.

10. UNIDO. Integrated Assessment of Present Status of Environmentally-Sound Management of Wastes in Africa. Africa Review Report on Waste Management. In Proceedings of the Sixth Session of the Committee on Food Security and Sustainable Development (CFSSD-6)/Regional Implementation Meeting (RIM) for CSD-18, Addis Ababa, Ethiopia, 27-30 October 2009.

11. Rai, R.K.; Nepal, M.; Khadayat, M.S.; Bhardwaj, B. Improving municipal solid waste collection services in developing countries: A case of bharatpur metropolitan city, Nepal. Sustainability 2019, 11, 3010. [CrossRef]

12. Zurbrugg, C. Solid Waste Management in Developing Countries. SWM Introductory Text, 2003; Volume 5. Available online: www.sanicon.net (accessed on 18 March 2021).

13. MUDC. Solid Waste Management Manual: With Respect to Urban Plans, Sanitary Landfill Sites and Solid Waste Management Planning; Urban Planning, Sanitation and Beautification Bureau: Addis Ababa, Ethiopia, 2012.

14. Ferronato, N.; Torretta, V. Waste mismanagement in developing countries: A review of global issues. Int. J. Environ. Res. Public Health 2019, 16, 1060. [CrossRef] [PubMed]

15. Kuma, T. Dry Waste Management in Addis Ababa City: Accounting for Urban Environment; Ethiopian Development Research Institute: Addis Ababa, Ethiopia, 2004.

16. World Bank. Solid Waste Landfills in Middle- and Lower-Income Countries. A Technical Guide to Planning, Design, and Operation; The International Bank for Reconstruction and Development; The World Bank: Washington, DC, USA, 1999.

17. Sharma, A.; Battula, R.B. Architecture for Waste Management in Indian Smart Cities (AWMINS). In Proceedings of the 2019 International Conference on Information and Communication Technology Convergence (ICTC), Jeju, Korea, 16-18 October 2019; pp. 76-83.

18. Ottelé, M. The green building envelope. In Civil Engineering and Geosciences; SiecaRepro: Delft, The Netherlands, 2011.

19. Regassa, N.; Sundaraa, R.D.; Seboka, B.B. Challenges and Opportunities in Municipal Solid Waste Management: The Case of Addis Ababa City, Central Ethiopia. J. Hum. Ecol. 2011, 33, 179-190. [CrossRef]

20. Godfrey, L.; Ahmed, M.T.; Gebremedhin, K.G.; Katima, J.H.; Oelofse, S.; Osibanjo, O.; Richter, U.H.; Yonli, A.H. Solid Waste Management in Africa: Governance Failure or Development Opportunity? Reg. Dev. Afr. 2019, 235. [CrossRef]

21. Yoshida, M. Situation of municipal solid waste management in African Cities-An interpretation of the information provided by the first ACCP meeting. In The Second Meeting of African Clean Cities Platform (ACCP); African Clean Cities Platform: Maputo, Mozambique, 2018.

22. Central Statistical Agency of Ethiopia (CSA). Population and Housing Census of Ethiopia: Statistical Report Urban Employment and Unemployment Survey; Central Statistical Agency of Ethiopia: Addis Ababa, Ethiopia, 2012. 
23. Alam, P.; Ahmade, K. Impact of solid waste on health and the environment. Int. J. Sustain. Dev. Green Econ. (IJSDGE) 2013, 2, 165-168.

24. Briggs, D. Environmental pollution and the global burden of disease. Br. Med. Bull. 2003, 68, 1-24. [CrossRef] [PubMed]

25. Chadar, S.N.; Keerti, C. Solid waste pollution: A hazard to environment. Recent Adv. Petrochem. Sci. 2017, 2, 1-3.

26. Cheru, M. Solid Waste Management in Addis Ababa: A New Approach to Improving the Waste Management System. Bachelor Thesis, Helsinki Metropolia University of Applied Sciences, Vantaa, Finland, 2016.

27. Zewdie, T. Groundwater Pollution and Public Health Risk Analysis in the Vicinity of Reppi Solid Waste Dumping Site, Addis Ababa City Ethiopia. Master Thesis, Addis Ababa Uiversity, Addis Ababa, Ethiopia, 2007. Unpublished.

28. Tsegaye, F. Assessment of Management Options for Domestic Solid Waste in Addis Ababa (Case Study of French Legasion Area). Master Thesis, Addis Ababa Uiversity, Addis Ababa, Ethiopia, 2007. Unpublished.

29. Tilay, M.; van Dijk, M.P. Sustainable Solid Waste Collection in Addis Ababa: The Users' Perspective. Int. J. Waste Resour. 2014, 4, 158. [CrossRef]

30. Mohammed, A.; Elias, E. Domestic solid waste management and its environmental impacts in Addis Ababa city. J. Environ. Waste Manag. 2017, 4, 194-203.

31. Beyene, H.; Banerjee, S. Assessment of the pollution status of the solid waste disposal site of Addis Ababa City with some selected trace elements, Ethiopia. World Appl. Sci. J. 2011, 14, 1048-1057.

32. SBPA. Current Status of Solid Waste Management of Addis Ababa; SBPA: Addis Ababa, Ethiopia, 2004.

33. Addis Ababa Solid Waste Management Agency. Municipal Solid Waste Generation Rate and Characterization Study Report; Addis Ababa Solid Waste Management Agency: Addis Ababa, Ethiopia, 2020.

34. Bello, I.A.; Bin Ismail, M.N.; Kabbashi, N.A. Solid waste management in Africa: A review. Int. J. Waste Resour. 2016, 6, 1-4.

35. van Niekerk, S.; Weghmann, V.; Municipal Solid Waste Management Services in Africa. Ferney-Voltaire: PSI (PSIRU Working Paper). 2019. Available online: www.world-psi.org/en/municipal-solid-waste-management-servicesafrica (accessed on 18 March 2021).

36. Sarkodie, S.A.; Owusu, P.A. Impact of COVID-19 pandemic on waste management. Environ. Dev. Sustain. 2021, 23, 7951-7960. [CrossRef]

37. Nzeadibe, T.C.; Ejike-Alieji, A.U. Solid waste management during Covid-19 pandemic: Policy gaps and prospects for inclusive waste governance in Nigeria. Local Environ. 2020, 25, 527-535. [CrossRef]

38. Vergara, S.E.; Tchobanoglous, G. Municipal solid waste and the environment: A global perspective. Annu. Rev. Environ. Resour. 2012, 37, 277-309. [CrossRef]

39. Ahsan, A.; Alamgir, M.; El-Sergany, M.M.; Shams, S.; Rowshon, M.K.; Daud, N.N. Assessment of municipal solid waste management system in a developing country. Chin. J. Eng. 2014, 2014, 1-11. [CrossRef]

40. Sallwey, J.; Hettiarachchi, H.; Hülsmann, S. Challenges and opportunities in municipal solid waste management in Mozambique: A review in the light of Nexus thinking. AIMS Environ. Sci. 2017, 4, 621-639. [CrossRef]

41. Orhorhoro, E.K.; Oghoghorie, O. Review on solid waste generation and management in sub-Saharan Africa: A case study of Nigeria. J. Appl. Sci. Environ. Manag. 2019, 23, 1729-1737. [CrossRef]

42. Eriksson, O.; Reich, M.C.; Frostell, B.; Björklund, A.; Assefa, G.; Sundqvist, J.O.; Granath, J.; Baky, A.; Thyselius, L. Municipal solid waste management from a systems perspective. J. Clean. Prod. 2005, 13, 241-252. [CrossRef]

43. Ayilara, M.S.; Olanrewaju, O.S.; Babalola, O.O.; Odeyemi, O. Waste management through composting: Challenges and potentials. Sustainability 2020, 12, 4456. [CrossRef]

44. Trivedi, S.; Chahar, O.; Mehta, K. Solid Waste Management Using Composting Technology. J. Ecol. Environ Ment. Sci. 2015, 6, 147-153.

45. Taiwo, A.M. Composting as a sustainable waste management technique in developing countries. J. Environ. Sci. Technol. 2011, 4, 93-102. [CrossRef]

46. Gunsilius, E. Recovering Resources, Creating Opportunities: Integrating the Informal Sector into Solid Waste Management; Dt. Gesellschaft für Intern, Zusammenarbeit (GIZ): Bonn, Germany, 2011.

47. Guerrero, L.A.; Maas, G.; Hogland, W. Solid waste management challenges for cities in developing countries. Waste Manag. 2013, 33, 220-232. [CrossRef]

48. Henry, R.K.; Yongsheng, Z.; Jun, D. Municipal solid waste management challenges in developing countries-Kenyan case study. Waste Manag. 2006, 26, 92-100. [CrossRef]

49. Pokhrel, D.; Viraraghavan, T. Municipal solid waste management in Nepal: Practices and challenges. Waste Manag. 2005, 25, 555-562. [CrossRef] [PubMed]

50. Cabeza, L.F.; Rincón, L.; Vilariño, V.; Pérez, G.; Castell, A. Life cycle assessment (LCA) and life cycle energy analysis (LCEA) of buildings and the building sector: A review. Renew. Sustain. Energy Rev. 2014, 29, 394-416. [CrossRef]

51. Amaral, R.E.; Brito, J.; Buckman, M.; Drake, E.; Ilatova, E.; Rice, P.; Sabbagh, C.; Voronkin, S.; Abraham, Y.S. Waste Management and Operational Energy for Sustainable Buildings: A Review. Sustainability 2020, 12, 5337. [CrossRef]

52. Hoornweg, D.; Thomas, L.; Otten, L. Composting and its applicability in developing countries. World Bank Work. Pap. Ser. 1999, 8, 1-46. 
53. Airan, D.S.; Bell, J.H. Resource recovery through composting-A sleeping giant. In Supplement-Discussions of 1980 National Waste Processing Conference: Ninth Biennial Conf.: Resource Recovery Today and Tomorrow; Papers Presented, Washington, DC/Sponsored by ASME Solid Waste Processing Division; American Society of Mechanical Engineers: New York, NY, USA, 1981.

54. Pioncelot, R.P. A scientific examination of the principles and practices of composting. Compos. Sci. 1974, 15, 24-31.

55. Cointreau, S. Environmental Management of Urban Solid Waste in Developing Countries; International Bank for Reconstruction and Development: Washington, DC, USA, 1982.

56. Akadiri, P.O.; Chinyio, E.A.; Olomolaiye, P.O. Design of a sustainable building: A conceptual framework for implementing sustainability in the building sector. Buildings 2012, 2, 126-152. [CrossRef]

57. $\mathrm{Wu}, \mathrm{Z}$; Shen, L.; Yu, A.T.W.; Zhang, X. A comparative analysis of waste management requirements between five green building rating systems for new residential buildings. J. Clean. Prod. 2016, 112, 895-902. [CrossRef]

58. Ann, C.M.; Abualrejal, H.M. Energy efficiency in green building to achieve company sustainability. In Proceedings of Symposium on Technology Management and Logistics (STMLGoGreen); Universiti Utara Malaysia: Bukit Kayu Hitam, Malaysia, December 2015; Volume 8, p. 9. 